\title{
Innovation And Knowledge Flows In Healthcare Ecosystems: The Portuguese Case
}

\author{
Daniel Ferreira Polónia, ${ }^{1,2}$ and Adriana Coutinho Gradim ${ }^{1}$ \\ ${ }^{1}$ Economics, Management, Industrial Engineering and Tourism Department, University of Aveiro \\ ${ }^{2}$ GovCOPP (Governance, Competitiveness and Public Policies) Research Group, Campus \\ Universitário de Santiago, Aveiro \\ dpolonia@ua.pt \\ adrianacoutinho@ua.pt
}

\begin{abstract}
Innovation has come a long way since the times it was defined just as a new idea. Nowadays, innovation activities comprise a lot more, from new products and/or services to improvements in organisational business models. The healthcare sector is no exception. This leads public authorities to increase their investment in innovation, research and development in the healthcare sector. The rising of internal and external collaborations between hospitals and other parties calls for a specific analysis on how the healthcare innovation environments behave and how knowledge flows within them are managed. This study, through the lens of the ecosystem theory, aims to study how a healthcare innovation ecosystem can be activated and knowledge flows are managed to ensure that all the parties are benefited. For that purpose, it presents a case study based on a set of three meetings of Portuguese stakeholders inserted in innovation healthcare ecosystems. With this work it was possible to observe that the healthcare innovation ecosystem can be analysed from different perspectives. The interaction with the different stakeholders allowed to identify possible partners to be involved in innovation activities (e.g.: hospitals, universities, research centres, start-ups). This paper suggests possible roles for the different parties along the innovation funnel as well as what they can do in each phase. Using a case study approach, it is possible to compare different contexts and identify best practices on the management of healthcare innovation ecosystems. Also, it becomes evident the need for more effective knowledge management to ensure that hospitals and the other parties meet their goals and play a relevant role in the ecosystem. Although this paper provides guidelines for action, it lacks implementation of the suggestions in a specific context. As such, this paper aims to serve as a basis for future research on the study of hospitals' innovation ecosystems and underlying knowledge flows, in different contexts to achieve best practices for its effective management.
\end{abstract}

Keywords: healthcare innovation ecosystem; ecosystem theory; knowledge flows; knowledge transfer; stakeholders; hospitals

\section{Introduction}

The ability to innovate is often considered a key factor to achieve sustained growth, especially in an everincreasingly ageing society that values wellbeing and health (Tolstykh, Gamidullaeva and Shmeleva, 2020). This leads public authorities to increase their investment in innovation, research and development in the healthcare sector, calling for a specific analysis on how the healthcare innovation environments behave and how knowledge flows within them are managed. Despite the importance of the theme, and although the subject of innovation ecosystems and its underlying flow of knowledge has been thoroughly studied in other contexts, very few of these studies address the specific case of healthcare, namely hospitals.

Nowadays, hospitals need to innovate not only internally (through the offering of new services, for example), but also externally, through collaborations with other organisations in the development of new solutions. As a result, the analysis of innovation ecosystems has benefited from extensive literature. The advantage of using the ecosystem approach relies on the fact that it considers the complexity of the business network established among a large number of actors and the interdependencies among them (Adner, 2017; Cavallo, Ghezzi and Balocco, 2018), .

The aim of this study is to analyse how it is possible to activate innovation and knowledge flows in healthcare ecosystems and ensure that all the participants benefit from its results, through a case study based on a group of Portuguese stakeholders. Moreover, this work aims to elaborate a set of best practices for the different stakeholders of the healthcare ecosystem that can promote innovation and knowledge flows among the entities. These guidelines relate to the different stages of the innovation process so that stakeholders can identify what to do along the process. Moreover, we would like to thank the 26 participants in this study, for their opinions and involvement. 
The paper is structured as follows: first, an introduction to the paper subject, followed by the methodology applied. Thirdly, the theoretical background. After, the results are presented, followed by its discussion, implications and limitations and conclusions.

\section{Theoretical background}

\subsection{Innovation and knowledge flows in the healthcare sector}

Innovation can be defined from various points of view, leading to the development of different types of innovation process models (Žižlavský, 2013; OECD/Eurostat, 2018). For this study, innovation is defined as the ideation and/or implementation of a new or improved product/service, process or business model (Dias and Escoval, 2014; Kelly and Young, 2017).

Depending on their goals, organisations must decide how they intend to innovate, using closed or open innovation (Chesbrough, 2012). This means that firms can choose between following an approach where they must generate ideas, develop and market them on their own, or an approach where they can use external ideas and even resources to maximize their knowledge (Bianchi et al., 2011; Adner, 2017).

Nowadays, open innovation is often associated with the concept of globalisation and the development of new and innovative solutions in the organisations (Bogers, Chesbrough and Moedas, 2018). Using this approach, managers must decide between an inbound or an outbound open innovation strategy. It means that an organisation can choose to open the innovation process to knowledge exploration, or opening the innovation process to knowledge exploitation (Lichtenthaler, 2011). In both cases, there is a need to develop relationships with external parties (Bianchi et al., 2011; Ribeiro and Nagano, 2018).

According to literature, hospitals appear to choose more open innovation approaches to deal with today's challenges (e.g. ageing people, need for more personalised treatment) (Secundo et al., 2019; Peter et al., 2020). Nevertheless, healthcare professionals (mainly doctors and nurses) do not always welcome external knowledge. This happens due to a common misunderstanding of the innovation processes' goals, which can lead to the boycott of innovation activities in the organisation (Hellström et al., 2015; Carlucci, Mura and Schiuma, 2020).

To improve the current paradigm, hospitals managers need to open their institutions and collaborate with other parties to achieve better innovation results (Dias and Escoval, 2013, 2014; Secundo et al., 2019). However, when establishing collaborations with other parties, tensions in the system can emerge due to a misalignment of the interests of the participants (Lantos and Simon, 2018).

Since it has been argued that the economics of the $21^{\text {st }}$ century are mainly characterised by knowledge, information and innovation, the knowledge and technology transfers are not only important within the organisation, but also between different organisations. (Žižlavský, 2013). The way these transfers are managed will strategically impact both sides of a collaborative partnership and the operationalisation of the innovation ecosystem (Shaw, 1988; ISO, 2019).

As such, hospitals need to manage not only internal knowledge but also the knowledge emerging from the networks created due to the "interaction and co-creation" across hospitals and other stakeholders in the system (Bianchi, et al., 2011; Lichtenthaler, 2011; Sieg, Wallin and von Krogh, 2019). Due to being a process driven service, the healthcare sector offers the opportunity to implement practices for the management of knowledge flows to improve existing processes (Bordoloi and Islam, 2012). However, due to the number and proximity among stakeholders involved in an innovation process the management of knowledge is challenging, since the different parties are known for playing different roles on an innovation ecosystem during the value creation process (Bordoloi and Islam, 2012; Lambooij and Hummel, 2013; Tranekjer, 2017; Scaringella and Radziwon, 2019).

The establishment of a sustainable ecosystem between different players and partners can lead to the creation of an unique environment, allowing a better business performance for all the involved parties (Järvi, Almpanopoulou and Ritala, 2018) acting as a key driver for the innovation process (Suominen, Seppänen and Dedehayir, 2019). Still, to achieve successful goals, the interested parties must understand what each can do in the process and anticipate interdependencies that arise from the process (Wilson and Doz, 2012; Thune and Mina, 2016). As important as identifying the network that can be formed during the innovation process, is the 
identification of partners and the correct management of the ecosystem through the identification of the ties that can be established and the knowledge flows that can be enacted (see Figure 1). Since knowledge management has the power to improve processes in the healthcare sector, the implementation of a mechanism to manage it is considered an essential tool to achieve efficiency in all areas (Bordoloi and Islam, 2012; Massaro, Dumay and Garlatti, 2015).

Hospital managers must be aware that their institutions work in an unique context in which stakeholders are vast and act different from the private sector (Riege and Lindsay, 2006; Massaro, Dumay and Garlatti, 2015). So, the management of knowledge flows must consider elements related to people, processes and technology (Edwards, 2011; Ford and Yoho, 2020). Moreover, the implementation of knowledge management practices can help to improve efficiency in all areas of the sector (Massaro, Dumay and Garlatti, 2015; Shabbir and Gardezi, 2020).

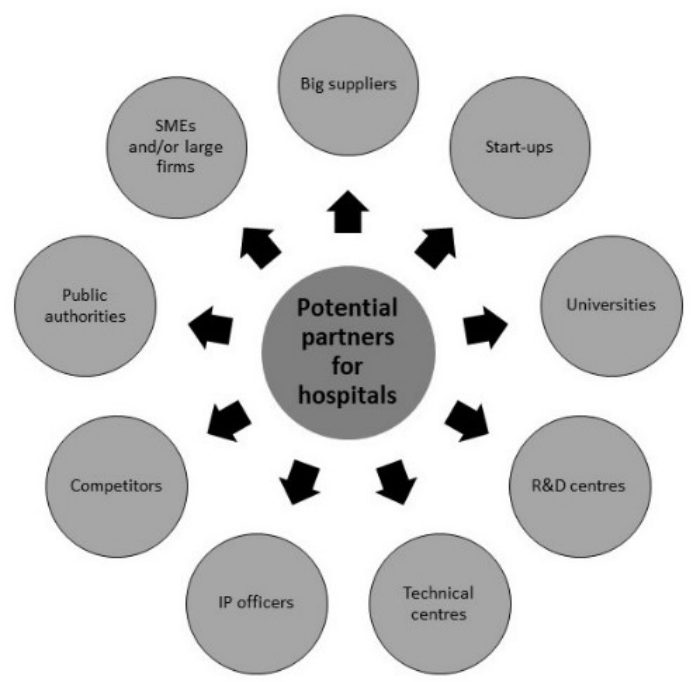

Figure 1: Suggested actors in the healthcare ecosystem. Adapted from ISO 56003:2019

\subsection{Ecosystem Theory}

In literature it is mentioned the need to study in more detail the healthcare ecosystem in what relates to innovation creation and its underlying knowledge flows (Secundo et al., 2019). This concept first emerged from the field of biology and refers to a complex system, hosting a number of entities and elements (Adner, 2017) and continued to be improved until it reached the management literature in mid 1990s (Cavallo, Ghezzi and Balocco, 2018; Scaringella and Radziwon, 2019).

Considering the necessities of the current business world, the innovation ecosystems are gaining importance as a lever to foster innovation in organisations (Secundo et al., 2019; Suominen, Seppänen and Dedehayir, 2019; Arenal et al., 2020). As mentioned previously, hospitals and healthcare institutions need to reposition themselves in the way they interact with society. To support this process, the concept of innovation ecosystems can play a guiding role. Since it includes a larger variety of actors, and the knowledge and the technology transferred among them resides in the interactions among the members, the ecosystem theory can help to implement new approaches (Secundo et al., 2019). The effective management of knowledge flows ensures the safety of sharing while guaranteeing that the "unresolved questions are not missed" (Maženytè and Petraitè, 2020).

Although theoretical concepts on healthcare innovation ecosystems are formally developed, very few case studies have been found in literature (while searching TOPIC "healthcare innovation ecosystem" or "healthcare knowledge ecosystem" and TOPIC "case study"). The works found are listed in Table 1, as it may help future research. 
Table 1: Papers found using TOPIC "healthcare innovation ecosystem" or "healthcare knowledge ecosystem" and TOPIC "case study"

\begin{tabular}{|c|l|l|}
\hline Year & \multicolumn{1}{|c|}{ Title } & \multicolumn{1}{|c|}{ Author(s) } \\
\hline 2020 & Opening new pathways for innovation in healthcare & Pavani, C.; Plonski, G.A. \\
\hline 2019 & Responsible for responsibility? A study of e-health start-ups & $\begin{array}{l}\text { Oftedal, E.M.; Foss, L.; } \\
\text { lakovleva, T. }\end{array}$ \\
\hline 2018 & $\begin{array}{l}\text { Understanding Convergent Innovation in Healthcare Technologies: Relational } \\
\text { Models for Nascent Ecosystems }\end{array}$ & Phillips, M. A. \\
\hline 2018 & $\begin{array}{l}\text { Intellectual property evolution and innovation ecosystem as effective tools in } \\
\text { strengthening Indian healthcare sector }\end{array}$ & $\begin{array}{l}\text { Dixit, T.; Srivastava, S.; } \\
\text { Sahu, S.; Selvamurthy, W. }\end{array}$ \\
\hline 2018 & $\begin{array}{l}\text { Introducing a governance framework for the innovation ecosystems. The case } \\
\text { of the public healthcare innovation ecosystem in the Lombardy Region }\end{array}$ & Barbarossa, M. \\
\hline 2018 & $\begin{array}{l}\text { A methodology for case study research to analyse innovation platforms in } \\
\text { South African healthcare sector }\end{array}$ & $\begin{array}{l}\text { Dondofema, R. A.; } \\
\text { Grobbelaar, S. }\end{array}$ \\
\hline 2017 & $\begin{array}{l}\text { Development of an Interoperable Exchange, Aggregation and Analysis } \\
\text { Platform for Health and Environmental Data }\end{array}$ & Alakraa, M. \\
\hline 2017 & $\begin{array}{l}\text { Orchestration roles to facilitate networked innovation in a healthcare } \\
\text { ecosystem }\end{array}$ & Pikkarainen, M.; Ervasti, M. \\
\hline 2017 & The roles of Innovation Network Orchestrators in Healthcare Ecosystem & Pikkarainen, M.; Ervasti, M. \\
\hline 2017 & Networked commercialisation of medical innovation - personalised medicine & Korhonen, R. \\
\hline 2016 & $\begin{array}{l}\text { Governance of Digital Innovation in Regional Healthcare Innovation } \\
\text { Ecosystem }\end{array}$ & $\begin{array}{l}\text { Pistorio, A.; Gastaldi, L.; } \\
\text { Locatelli, P. }\end{array}$ \\
\hline 2016 & $\begin{array}{l}\text { Digital health innovation ecosystems: From systematic literature review to } \\
\text { conceptual framework }\end{array}$ & $\begin{array}{l}\text { Iyawa, G. E.; Herselman, } \\
\text { M.; Botha, A. }\end{array}$ \\
\hline 2015 & $\begin{array}{l}\text { Personal health systems technologies: critical issues in service innovation and } \\
\text { diffusion }\end{array}$ & $\begin{array}{l}\text { Schartinger, D.; Miles, I.; } \\
\text { Saritas, O. }\end{array}$ \\
\hline 2013 & $\begin{array}{l}\text { Accelerating digital health innovation: Analysing opportunities in the } \\
\text { healthcare innovation ecosystem }\end{array}$ & Cohen, E. \\
\hline 2011 & Workforce for innovative regulatory science & Olson, S.; Claiborne, A. B. \\
\hline
\end{tabular}

As such, this article aims to contribute to this gap in knowledge by bringing together the elements of the Portuguese healthcare ecosystem, identify its internal strengths and weaknesses and analyse its external opportunities and threats. So, the following research question emerged: How it is possible to activate innovation and knowledge flows in healthcare ecosystems and ensure that all the participants benefit from its results?

\section{Methods}

Considering the Portuguese healthcare sector, there is a clear lack of innovation initiatives that connect hospitals with the academia, the industry, the government and the civil society (Dias and Escoval, 2014; Moreira, Gherman and Sousa, 2017).

To validate this perception, a literature review was carried focused on innovation in the healthcare sector and/or ecosystem and the underlying knowledge flows, as well as the role of stakeholders in the ecosystem and a brief review of the theories supporting the study.

To help answering the research question, elements from organisations that belong to the healthcare ecosystem (such as hospitals, universities/research centres, pharmaceutical companies, small and medium enterprises (SMEs), start-ups, public authorities and patients' associations) were selected to participate in meetings through three rounds This technique allows to select individuals that have experience on a certain subject, according to a set of criteria. In this case, each individual had to be member of an entity that is included in the Portuguese healthcare ecosystem and with experience on the area. Moreover, through the social interactions of the group, the results obtained tend to be better than individuals face-to-face interviews (Rabiee, 2004)

With this qualitative technique, the individuals were able to provide their ideas and opinions regarding the management of innovation in healthcare ecosystems in Portugal. The work group was composed by 26 individuals from different sectors. The inclusion of elements from diverse organisations allows to have a sample 
composed by organisations from the four helices of the quadruple helix model, namely society, government, academia and industry (Carayannis and Campbell, 2010; Hasche, Höglund and Linton, 2019).

Tables 2 and 3 show the sample characteristics based on gender and the function of each participant in the organisation. Table 4 characterizes the participating entities by framing them into the Quadruple Helix Model.

Table 2: Sample characteristics based on gender

\begin{tabular}{|c|c|c|}
\hline Gender & Masculine & Feminine \\
\hline Percentage & $61,5 \%$ & $38,5 \%$ \\
\hline Number & 16 & 10 \\
\hline Total & \multicolumn{2}{|c|}{$\mathbf{2 6}$} \\
\hline
\end{tabular}

Table 3: Sample characteristics based on function at the organisation

\begin{tabular}{|l|c|}
\hline Function & Number \\
\hline Professor & 4 \\
\hline Manager & 11 \\
\hline Director & 4 \\
\hline Board Member & 3 \\
\hline Consultant & 2 \\
\hline Researcher & 2 \\
\hline Total of participants & $\mathbf{2 6}$ \\
\hline
\end{tabular}

Table 4: Sample characteristics of the participating entities based on the Quadruple Helix Model

\begin{tabular}{|l|c|}
\hline Quadruple Helix Entities & Number \\
\hline Society & 1 \\
\hline Government & 7 \\
\hline Academia & 7 \\
\hline Industry & 5 \\
\hline Total of participating entities & $\mathbf{2 0}$ \\
\hline
\end{tabular}

The meetings were guided by information from the literature and personal knowledge of the performance of the healthcare innovation ecosystem in Portugal.

The first meeting focused on presenting the national context, thus identifying the strengths and weaknesses of the health innovation system and identifying best practices.

The second meeting complemented and validated the findings of the first meeting and made an initial discussion of the best practices identified.

The third meeting finished the SWOT/TOWS matrix and the best practices identification.

From the discussion, a set of strengths and weaknesses of the innovation ecosystem was identified as well as a set of opportunities and threats in the environment surrounding the ecosystem, that lead to the development of a TOWS matrix (Weihrich, 1982). The results of this matrix enabled the identification of lines of action that not only address the research question, but also lead to medium-term vision of how the healthcare ecosystem can be managed so that innovation can be achieved, and knowledge can flow among the members of the ecosystem.

\section{Results and discussion}

First, there was the need to identify the elements involved in the innovation process, considering the well-known "innovation funnel" process that describes how ideas are generated, turned into concepts, manufactured and them commercialised.

For this study, the state-owned hospital innovation ecosystem was the one considered. However, other healthcare innovation ecosystems can be identified such as the case of private hospitals and nursing homes, among others. 
Before providing the actions that each actor can play along the process, it must be defined the position of hospitals in it. Traditionally, state-owned hospitals are considered secondary actors in the development of new solutions, as suggested in Figure 2. This means that they enter in the process when contacted by other players and only perform the functions which are determined by others (Secundo et al., 2019). The results show evidence from the Portuguese case.

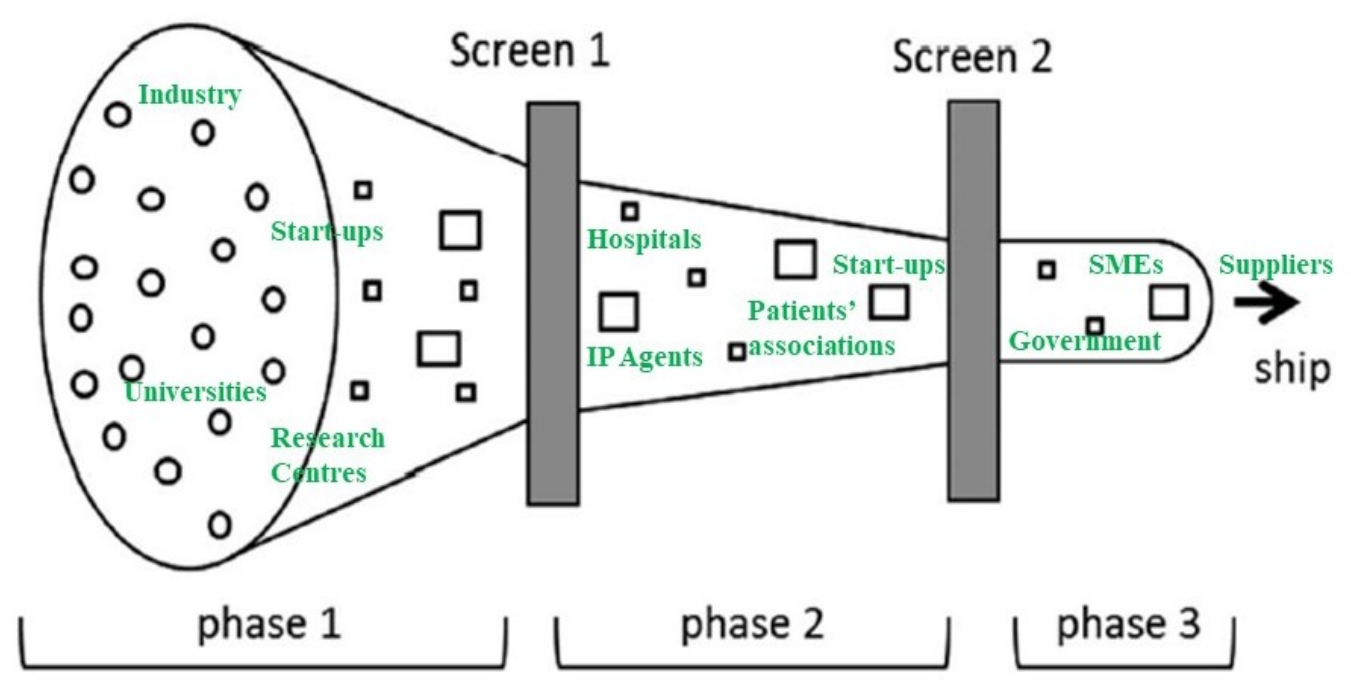

Figure 2: Suggested traditional position from hospitals in the healthcare innovation ecosystem. Adapted from (Bagno, Salerno and da Silva, 2017)

The Portuguese healthcare sector has a public portal that highlights the importance of innovation in healthcare. However, a health innovation strategy does not exist. These leads, in one hand, to the non-involvement of patients in the assessment of innovative solutions and, on the other hand, to SMEs and start-ups not being able to focus on the development of products that can be scaled up by the ecosystem.

Also, the individuals identified that the knowledge creation process is focused on the academia with few contacts with the healthcare institutions. The healthcare sector in Portugal is mainly composed by state-owned hospitals, which do not have a competitive nature and tend to ignore the need to incorporate innovation and the underlying knowledge when adopting new technologies. Therefore, as identified in the literature, technological innovation adoption is frequently prevented by the lack of partnerships between healthcare institutions and other parties in the ecosystem (Tidd and Bessant, 2009). One reason for this is that hospital managers have no incentive to hire innovation managers that can structure these relationships.

Although it seems that the healthcare sector in Portugal is facing serious difficulties, the people involved in this study identified some opportunities to improve it. Portugal can learn from other European countries who are leaders in innovation in the sector (e.g., see Øvretveit et al., 2012). It exists the opportunity to develop and incorporate new approaches that can lead to new and innovative business models, in which hospitals play a more central and decisive role, as identified in the literature (Dias and Escoval, 2012). Also, even though the EU data policy is restrictive, Portugal has the capacity to manage the existing data from patients, hospitals and other stakeholders through the development and implementation of new technological services. Therefore, a need for the introduction of new information systems that allow data standardisation, without compromising individual identification emerges. This can allow to define behavioural patterns and provide a better service, through the efficient management of knowledge flows (Laihonen, 2015).

The main contribution of this paper is the analysis of the results through a TOWS matrix. This technique allows to identify actions to leverage strengths and seize opportunities (SO); assess how threats can be accessed by the strengths (ST); understand which opportunities are not explored due to weaknesses (WO) and identify which threats are impacted seriously by the weaknesses (WT), as it can be seen in detail in Appendix 1.

Such technique helped to draw a set of guidelines to improve innovation and knowledge flow in the healthcare ecosystem while identifying actions that each player can perform in the healthcare ecosystem were identified, 
allowing to redefine the role of hospitals in it. These guidelines (Tables 5, 6 and 7) were defined considering each phase of the innovation process. As a result, the innovation funnel was redrawn in Figure 3, considering a more active role of hospitals in the ecosystem.

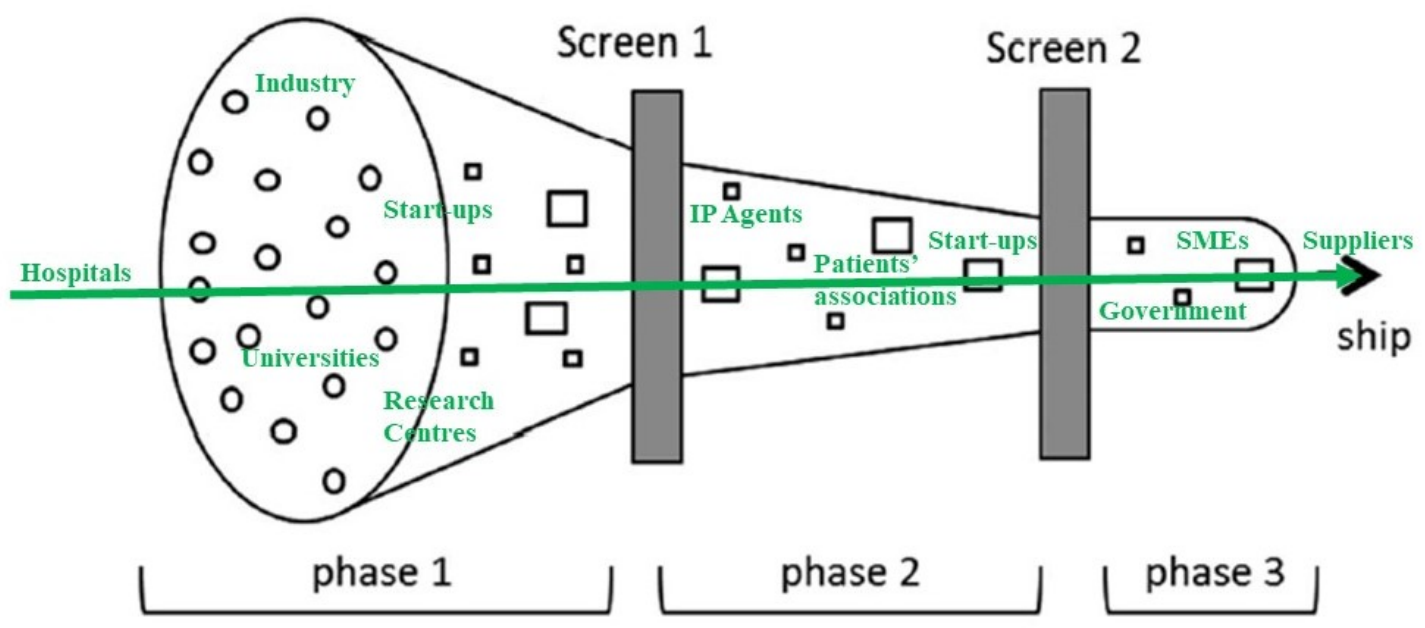

Figure 3: Suggested new hospital position in the healthcare innovation ecosystem. Adapted from (Bagno, Salerno and da Silva, 2017)

The first stage of the innovation process (ideation) refers to the product/service/process idea generation and selection, considering the viability and importance for the organisation. The aim of this stage is to collect as many ideas as possible to increase the possibilities of improvement by the organisation. Therefore, the goals of the parties involved as well as the responsibilities and the role each can play in the process must be well defined (Hakkarainen and Consulting, 2014; Bagno, Salerno and da Silva, 2017).

Table 5: Actors and suggested actions in the first phase (ideation) of the innovation process

\begin{tabular}{|c|c|}
\hline Actor of the ecosystem & Actions suggested \\
\hline Universities & $\begin{array}{l}\text { Encourage the participation of the students in innovation projects in the } \\
\text { healthcare sector; } \\
\text { Inclusion of management disciplines in the healthcare courses to enable } \\
\text { commercialisation of research results; } \\
\text { Promote the integration of medicine students in projects from other areas } \\
\text { such as management to empower them with other skills; } \\
\text { Promote dynamics of contact with different entities of the healthcare } \\
\text { innovation ecosystem to study how knowledge is managed; } \\
\text { Promote training in entrepreneurship activities. }\end{array}$ \\
\hline Research centres & $\begin{array}{l}\text { Test and validate pilots and projects in the market; } \\
\text { Make the results from projects and pilots available and accessible for } \\
\text { companies that are willing to transform them into commercial products. }\end{array}$ \\
\hline Start-ups & $\begin{array}{l}\text { Define their role in the innovation process and operate according to the } \\
\text { resources available (human, financial, engineering, etc); } \\
\text { Promote the participation of elements from staff in conferences and other } \\
\text { relevant events related to the development of innovative approaches in } \\
\text { the healthcare sector to be updated; } \\
\text { Hire knowledgeable people in the healthcare field to become relevant in } \\
\text { the market and know how to operate in it. }\end{array}$ \\
\hline
\end{tabular}

Moving to the second stage (proof of concept), in this phase there is space to develop the concept, detailing the project and requirements for further development and implementation, according to defined criteria. The ideas must be matched according to the goals of the ecosystem, while choosing approaches to test the concept (Hakkarainen and Consulting, 2014; Bagno, Salerno and da Silva, 2017). 
Table 6: Actors and actions suggested in the second stage (proof of concept) of the innovation process

\begin{tabular}{|l|l|}
\hline Actor of the ecosystem & Actions suggested \\
\hline Start-ups & $\begin{array}{l}\text { Select the most suitable stakeholder for the project and enter } \\
\text { networking and knowledge transfer agreements with other } \\
\text { stakeholders; } \\
\text { Identify funding opportunities that enable the creation of marketable } \\
\text { products. }\end{array}$ \\
\hline Patients associations & $\begin{array}{l}\text { Promote the participation of patients in clinical tests to assess the } \\
\text { performance of innovative solutions; } \\
\text { Promote the use of information systems in the healthcare sector by } \\
\text { patients to express their needs and opinions; } \\
\text { Promote the advantages for the patients that result from participating } \\
\text { in the innovation ecosystem. }\end{array}$ \\
\hline Intellectual Property (IP) Agents & $\begin{array}{l}\text { Must be integrated in the innovation process since its beginning to } \\
\text { guarantee that the objectives of the project do not duplicate existing } \\
\text { results and that the intended results are properly protected; } \\
\text { Must act as neutral parties, guaranteeing that each participant in the } \\
\text { ecosystem is properly rewarded for its involvement and has a stake in } \\
\text { the IP generated and receives adequate royalties from the } \\
\text { commercialisation of IP. }\end{array}$ \\
\hline
\end{tabular}

The last phase of the innovation funnel refers to the manufacturing, distribution and sales, which consists in releasing the new product/service or implement a new process/business model (Hakkarainen and Consulting, 2014; Bagno, Salerno and da Silva, 2017).

Table 7: Actors and actions suggest in the third phase (manufacturing, distribution and sales) of the innovation process

\begin{tabular}{|l|l|}
\hline Actors & Actions suggested \\
\hline SMEs & $\begin{array}{l}\text { Focus on proactively performing competitive assessments of the research and } \\
\text { development results that show potential to be transformed into commercial } \\
\text { products; } \\
\text { Integrate consortia that links them with companies from other countries enabling } \\
\text { learning processes and accessing new funding opportunities, exposing them to new } \\
\text { markets; } \\
\text { Perform proactively a risk-assessment analysis that highlights the main problems } \\
\text { and difficulties that they may have during the fulfilment of the innovation process. }\end{array}$ \\
\hline Suppliers (large companies) & $\begin{array}{l}\text { Align business agenda with the main research themes addressed by research centres } \\
\text { in the ecosystem; } \\
\text { Promote the integration of different parties in the innovation process. For that, it is } \\
\text { necessary to strike a balance from its participation in the ecosystem (i.e. benefiting } \\
\text { from it while, at the same time, promoting the emergence of new players); } \\
\text { Considering the emergence of new players, leverage the existing physical and } \\
\text { financial infrastructure to guide promising research towards the marketplace }\end{array}$ \\
\hline $\begin{array}{l}\text { Public } \\
\text { authorities/government }\end{array}$ & $\begin{array}{l}\text { Fund the development of a platform where the stakeholders of a healthcare } \\
\text { innovation ecosystem can establish long-term relationships with underlying support } \\
\text { structures; } \\
\text { Create a national healthcare innovation strategy through the disclosure of } \\
\text { opportunities to develop innovate solutions (at a regional, national and European } \\
\text { levels); } \\
\text { Develop a new approach to reduce the bureaucratic processes and make the } \\
\text { information publicly available and easy to access; } \\
\text { Review the current funding model of healthcare institutions, considering a value- } \\
\text { based healthcare strategy, which aims to increase the investment in research, } \\
\text { development, and innovation, }\end{array}$ \\
\hline
\end{tabular}

Considering the continuous role of the hospitals in the process, the following key approaches were identified. Hospitals must try to define an innovation agenda that they can manage in the medium and long-term relationships, being able to quantify the benefits of participating in the ecosystem. Also, they should promote 
the participation of patients and staff in innovation projects by providing more information and showing its benefits to the users, promoting data collection, analysis and treatment for knowledge creation.

Hiring innovation managers, to supervise innovation processes in the hospital and the surrounding ecosystem, can play a decisive part in enhancing the role and responsibilities of the hospital in the innovation process. The integration of a knowledge and technology manager in the institution is important to ensure that the parties are levelled and are communicating on a peer to peer basis.

Also, it is suggested that according to the resources available, hospitals must try to leverage their position in the innovation process while seeking to obtain a more active role that can benefit their participation in this type of projects.

As it can be seen, a significant number of stakeholders can be identified in the healthcare innovation ecosystem as well as actions that each can take, which implies an intensive change of knowledge. From these results, this paper suggests the creation of an online platform where participants in the healthcare sector can find stakeholders to develop innovative solutions - from consortia identification to market results, ensuring the adequate funding mechanisms and support activities necessary to achieve these results.

As such, there is the need to implement knowledge flows management practices, to ensure successful collaborations. However, the role of the stakeholder depends on the goals of the ecosystem, the goals of each participant and the resources each party is willing to provide. This validates the use of the ecosystem approach, since it considers a large number of actors and the tensions that can emerge from the collaborations established.

Answering the research question, the creation and development of the ecosystem is only possible and activated if the existing strengths can be properly leveraged. This can happen through the creation of an innovation platform that ignites, guide and support the relationships between stakeholders during the entire innovation process life cycle. Along the process, there is also the need to implement knowledge management practices, that are complex in the public sector (Massaro, Dumay and Garlatti, 2015). However, some effort must be made to ensure that these practices are implemented. Also, the need to manage knowledge needs to be communicated between all the parties involved in the ecosystem, so that knowledge can flow and improve the work developed in the network.

\section{Conclusion}

Innovation has come a long way since the times it was defined just as a new idea. Nowadays, innovation activities range from the development of new products and/or services to improvements in organisational business models. The healthcare sector is no exception. Innovation in this sector as being increasing over time and in the last years it has occupied a prominent place in the national and European agenda.

With this study it was possible to observe that the healthcare innovation ecosystem can be analysed from different perspectives. However, it is important to emphasize the role of the hospital in the process, to achieve better results and improve their innovative capabilities. Using a case study approach, it will be possible to compare different contexts and achieve best practices on the management of healthcare innovation ecosystems.

Also, the need for more effective knowledge management and technology practices is evident to ensure that hospitals and the other parties meet their goals and play their role in the ecosystem.

Finally, to answer to the research question, our perception is clear. It is only possible to activate innovation and knowledge flows in healthcare ecosystems and ensure that all the participants benefit from its results and for that to happen, it is necessary to have a catalyser (an entity or individual) that is responsible for finding the best partnership opportunities to innovate.

\subsection{Implications}

This work has strived to understand the necessary conditions for the creation of such an ecosystem, identifying the current status quo, its strengths and weaknesses, as well as external opportunities and threats. 
Based on the existing characteristics, a road map proposal was defined that can contribute to the emergence of a healthcare innovation ecosystem from which all parties can benefit and pursue, in a more rational and practical approach their research and business objectives. Also, this study identifies the pertinence of developing an online platform to manage the innovation ecosystem and its stakeholders, which currently does not exist in the country.

\subsection{Limitations and future research suggestions}

Although the paper provided guidelines for action, there is the lack of implementation of the suggestions in a specific context. So, this paper aims to serve as a basis for future research on the study of hospitals' innovation ecosystems and knowledge flows among the involved parties.

Moreover, the development of case studies regarding the creation, development and maintenance of hospital innovation ecosystems in different contexts could help to achieve best practices for its effective management. Also, the enrichment of the literature, with the analysis of different regions could help to foster innovation in countries with low levels of innovation in the healthcare sector, since they could learn from others and among each other.

\section{References}

Adner, R., 2017 Ecosystem as Structure: An Actionable Construct for Strategy, Journal of Management, 43(1), pp. 39-58.

Arenal, A., Armuña, C., Feijoo, C., Ramos, S., Xu, Z. and Moreono, A., 2020 Innovation ecosystems theory revisited: The case of artificial intelligence in China, Telecommunications Policy, 44(6). doi: 10.1016/j.telpol.2020.101960.

Bagno, R. B., Salerno, M. S. and da Silva, D. O., 2017 Models with graphical representation for innovation management: a literature review, R\&D Management, 47(4), pp. 637-653.

Bianchi, M., Cavaliere, A., Chiaroni, D., Frattini, F. and Chiesa, V., 2011 Organisational modes for Open Innovation in the bio-pharmaceutical industry: An exploratory analysis, Technovation. 31(1), pp. 22-33. doi: 10.1016/j.technovation.2010.03.002.

Bogers, M., Chesbrough, H. and Moedas, C., 2018 Open innovation: research, practices, and policies, California Management Review, 60(2), pp. 5-16.

Bordoloi, P. and Islam, N., 2012 Knowledge Management Practices and Healthcare Delivery : A Contingency Framework, Electronic Journal of Knowledge Management, 10(2), pp. 110-120.

Carayannis, E. G. and Campbell, D. F. J., 2010 Triple helix, Quadruple helix and Quintuple helix and how do Knowledge, Innovation and the Environment relate to Each other? a proposed framework for a trans-disciplinary analysis of sustainable development and social ecology, International Journal of Social Ecology and Sustainable Development, 1(1), pp. 41-69. doi: 10.4018/jsesd.2010010105.

Carlucci, D., Mura, M. and Schiuma, G., 2020 Fostering Employees' Innovative Work Behaviour in Healthcare Organisations, International Journal of Innovation Management, 24(2)., pp. 1-28. doi: 10.1142/S1363919620500140.

Cavallo, A., Ghezzi, A. and Balocco, R., 2018 Entrepreneurial ecosystem research: present debates and future directions, International Entrepreneurship and Management Journal, 15, pp. 1291-1321. doi: 10.1007/s11365-018-0526-3

Chesbrough, H., 2012 Open innovation: Where we've been and where we're going, Research Technology Management, 55(4), pp. 20-27. doi: 10.5437/08956308X5504085.

Dias, C. and Escoval, A., 2012 The open nature of innovation in the hospital sector: The role of external collaboration networks, Health Policy and Technology. 1(4), pp. 181-186. doi: 10.1016/j.hlpt.2012.10.002.

Dias, C. and Escoval, A., 2013 Improvement of hospital performance through innovation: Toward the value of hospital care, Health Care Manager, 32(3), pp. 268-279. doi: 10.1097/HCM.0b013e31828ef60a.

Dias, C. and Escoval, A., 2014 Hospitals as learning organizations: fostering innovation through interactive learning, Quality Management Health Care Journal, pp. 1-8. doi: 10.1097/qmh.0000000000000046.

Edwards, J., 2011 A process view of knowledge management:it ain't want you do, it's the way that you do it, Electronic Journal of Knowledge Management, 9(4), pp. 297-306.

Ford, R. C. and Yoho, K. D., 2020 The government's role in creating an innovation ecosystem: the Springfield Armory as hub in the Connecticut River Valley, Journal of Management History, 26(4), pp. 557-579. doi: 10.1108/JMH-02-20200016.

Hakkarainen, K. and Consulting, V., 2014 The Innovation Funnel Fallacy, International Journal of Innovation Science, 6(2), pp. 63-71. doi: 10.1260/1757-2223.6.2.63.

Hasche, N., Höglund, L. and Linton, G., 2019 Quadruple helix as a network of relationships: creating value within a Swedish regional innovation system, Journal of Small Business and Entrepreneurship. Routledge, 32(6), pp. 523-544. doi: 10.1080/08276331.2019.1643134.

Hellström, A., Lifvergren, S., Gustavsson, S. and Gremyr, I., 2015 Adopting a management innovation in a professional organization: The case of improvement knowledge in healthcare, Business Process Management Journal, 21(5), pp. 1186-1203. doi: 10.1108/BPMJ-05-2014-0041.

ISO, 2019 ISO - ISO 56003:2019 - Innovation management - Tools and methods for innovation partnership - Guidance. Available at: https://www.iso.org/standard/68929.html (Accessed: 28 May 2020). 
Järvi, K., Almpanopoulou, A. and Ritala, P., 2018 Organization and knowledge ecosystems: prefigurative and partial forms, Research Policy, 47, pp. 1523-1537.

Kelly, C. J. and Young, A. J., 2017 Promoting innovation in healthcare, Future Hospital Journal. Royal College of Physicians, 4(2), pp. 121-125. doi: 10.7861/futurehosp.4-2-121.

Laihonen, H., 2015 A managerial view of the knowledge flows of a health-care system, Knowledge Management Research \& Practice. 13(4), pp. 475-485. doi: 10.1057/kmrp.2014.3.

Lambooij, M. S. and Hummel, M. J., 2013 Differentiating innovation priorities among stakeholder in hospital care, BMC Medical Informatics and Decision Making, 13(1), pp. 1-11. doi: 10.1186/1472-6947-13-91.

Lantos, Z. and Simon, J., 2018 The Community Health Experience Model - Value generation from person-centered health transaction network, Public Health Reviews. Public Health Reviews, 39(1), pp. 1-19. doi: 10.1186/s40985-018-0105-8.

Lichtenthaler, U., 2011 Open innovation: Past research, current debates, and future directions, Academy of Management Perspectives, 25(1), pp. 75-93. doi: 10.5465/AMP.2011.59198451.

Massaro, M., Dumay, J. and Garlatti, A., 2015 Public sector knowledge management: A structured literature review, Journal of Knowledge Management, 19(3), pp. 530-558. doi: 10.1108/JKM-11-2014-0466.

Maženytė, B. and Petraite, M., 2020 Mediating knowledge across health ecosystems: a qualitative field study, Measuring Business Excellence, 24(1), pp. 52-68. doi: 10.1108/MBE-09-2019-0099.

Moreira, M. R. A., Gherman, M. and Sousa, P. S. A., 2017 Does innovation influence the performance of healthcare organizations?, Innovation: Management, Policy and Practice. Routledge, 19(3), pp. 335-352. doi: 10.1080/14479338.2017.1293489.

OECD/Eurostat, 2018 Oslo Manual 2018, Handbook of Innovation Indicators and Measurement. doi: 10.1787/9789264304604-en.

$\emptyset$ vretveit, J., Sachs, M. A., Carlsson, J., Gustafsson, H., Hansson, J., Keller, C., Lofgren, S., Mazzocato, P., Tolf, S. and Brommels, M., 2012 Implementing organisation and management innovations in Swedish healthcare: Lessons from a comparison of 12 cases, Journal of Health, Organisation and Management, 26(2), pp. 237-257. doi: $10.1108 / 14777261211230790$.

Peter, L., Hajek, L., Maresova, P., Augustynek, M. and Penhaker, M., 2020 Medical devices: regulation, risk classification, and open innovation, Journal of Open Innovation: Technology, Market, and Complexity, 6(42), pp. 1-13. doi: 10.3390/JOITMC6020042.

Rabiee, F., 2004 Focus-group interview and data analysis, Proceedings of the Nutrition Society, 63(4), pp. 655-660. doi: $10.1079 /$ pns2004399.

Ribeiro, S. X. and Nagano, M. S., 2018 Elements influencing knowledge management in university-business-government collaboration: Case studies in National Institutes of Science and Technology, Knowledge and Process Management, 25(3), pp. 207-219. doi: 10.1002/kpm.1576.

Riege, A. and Lindsay, N., 2006 Knowledge management in the public sector: Stakeholder partnerships in the public policy development, Journal of Knowledge Management, 10(3), pp. 24-39. doi: 10.1108/13673270610670830.

Scaringella, L. and Radziwon, A., 2019 Innovation, entrepreneurial, knowledge, and business ecosystems: Old wine in new bottles?, Technological Forecasting and Social Change, 136, pp. 59-87. doi: 10.1016/j.techfore.2017.09.023

Schoonmaker, M. G. and Carayannis, E. G., 2013 Mode 3: A Proposed Classification Scheme for the Knowledge Economy and Society, Journal of the Knowledge Economy, 4(4), pp. 556-577. doi: 10.1007/s13132-012-0097-4.

Secundo, G., Toma, A., Schiuma, G. and Passiante, G., 2019 Knowledge transfer in open innovation: A classification framework for healthcare ecosystems, Business Process Management Journal, 25(1), pp. 144-163. doi: 10.1108/BPMJ-06-2017-0173.

Shabbir, M. Q. and Gardezi, S. B. W., 2020 Application of big data analytics and organizational performance: the mediating role of knowledge management practices, Journal of Big Data. Springer International Publishing, 7(47), pp. 1-17. doi: 10.1186/s40537-020-00317-6.

Shaw, B., 1988 Gaining added value from centres of excellence in the UK medical equipment industry, R\&D Management, 18(2), pp. 123-130. doi: 10.1111/j.1467-9310.1988.tb00579.x.

Sieg, J. H., Wallin, M. W. and Von Krogh, G., 2019 Managerial challenges in open innovation: a study of innovation intermediation in the chemical industry, Research and Development Management, 40(3), pp. 281-291. doi: 10.1111/j.1467-9310.2009.00596.x.

Suominen, A., Seppänen, M. and Dedehayir, O., 2019 A bibliometric review on innovation systems and ecosystems: a research agenda, European Journal of Innovation Management, 22(2), pp. 335-360.

Thune, T. and Mina, A., 2016 Hospitals as innovators in the health-care system: A literature review and research agenda, Research Policy. 45(8), pp. 1545-1557. doi: 10.1016/j.respol.2016.03.010.

Tidd, J. and Bessant, J., 2009 Managing Innovation: Integrating Technological, Market and Organizational Change. Fourth Edi. West Sussex: John Wiley \& Sons, Ltd. doi: 10.1007/s13398-014-0173-7.2.

Tolstykh, T., Gamidullaeva, L. and Shmeleva, N., 2020 Elaboration of a mechanism for sustainable enterprise development in innovation ecosystems, Journal of Open Innovation: Technology, Market, and Complexity, 6(4), pp. 1-23. doi: 10.3390/joitmc6040095.

Tranekjer, T. L., 2017 Open innovation: effects from external knowledge sources on abandoned innovation projects, Business Process Management Journal, 23(5), pp. 918-935. doi: 10.1108/BPMJ-04-2016-0076.

Weihrich, H., 1982 The TOWS Matrix Situational Analysis, Long Range Planning, 15(2), pp. 54-66. 
Wilson, K. and Doz, Y. L., 201210 Rules for Managing Global Innovation, Harvard Business Review, pp. 84-90. Available at: https://hbr.org/2012/10/10-rules-for-managing-global-innovation (Accessed: 27 January 2021)

Žižlavský, O., 2013 Past, present and future of the innovation process, International Journal of Engineering Business Management, 5(3), pp. 1-8. doi: 10.5772/56920. 


\section{Appendix 1 - TOWS Analysis}

\begin{tabular}{|c|c|c|c|c|c|}
\hline & $\begin{array}{l}\text { O01. } \\
\text { Introduction of } \\
\text { informatic } \\
\text { software in the } \\
\text { healthcare } \\
\text { services }\end{array}$ & $\begin{array}{l}\text { O02. Management } \\
\text { of clinical data } \\
\text { among } \\
\text { stakeholders }\end{array}$ & $\begin{array}{l}\text { O03. New } \\
\text { business models }\end{array}$ & $\begin{array}{l}\text { O04. Learn from } \\
\text { other countries }\end{array}$ & $\begin{array}{l}\text { O05. Manage } \\
\text { clinical data to } \\
\text { negotiate with } \\
\text { pharmaceutics } \\
\text { and assess medical } \\
\text { equipment in a } \\
\text { large scale }\end{array}$ \\
\hline $\begin{array}{l}\text { S01. Public } \\
\text { platform that gives } \\
\text { importance to } \\
\text { innovation in the } \\
\text { healthcare sector }\end{array}$ & $\begin{array}{l}\text { The connection } \\
\text { between data } \\
\text { from the system } \\
\text { and the platform } \\
\text { could help to } \\
\text { identify } \\
\text { innovation } \\
\text { opportunities } \\
\text { more easily } \\
\text { according to the } \\
\text { patterns }\end{array}$ & $\begin{array}{l}\text { Connecting the } \\
\text { data to identify } \\
\text { hospitals where } \\
\text { innovation is more } \\
\text { rapidly growing }\end{array}$ & $\begin{array}{l}\text { Identification of } \\
\text { innovative } \\
\text { opportunities to } \\
\text { identify how } \\
\text { hospitals can } \\
\text { operate at a local } \\
\text { level based on } \\
\text { their experience }\end{array}$ & $\begin{array}{l}\text { Learn from } \\
\text { others of how } \\
\text { they assess } \\
\text { innovation } \\
\text { opportunities }\end{array}$ & $\begin{array}{l}\text { Data can help to } \\
\text { benchmark } \\
\text { partnerships, } \\
\text { evaluating them } \\
\text { periodically and } \\
\text { create incentive } \\
\text { mechanisms in the } \\
\text { medium and long- } \\
\text { term }\end{array}$ \\
\hline $\begin{array}{l}\text { S02. Structured } \\
\text { and integrated } \\
\text { information about } \\
\text { what is being done } \\
\text { in the healthcare } \\
\text { sector, available } \\
\text { for all users }\end{array}$ & $\begin{array}{l}\text { Promote sharing } \\
\text { of anonymous } \\
\text { data from } \\
\text { patients that can } \\
\text { help to identify } \\
\text { opportunities to } \\
\text { develop } \\
\text { innovative } \\
\text { solutions } \\
\end{array}$ & $\begin{array}{l}\text { Help to identify } \\
\text { opportunities for } \\
\text { the } \\
\text { implementation of } \\
\text { innovative } \\
\text { solutions }\end{array}$ & N/A & $\begin{array}{l}\text { In learning from } \\
\text { other countries, } \\
\text { the data can } \\
\text { help to identify } \\
\text { which initiatives } \\
\text { can be } \\
\text { developed and } \\
\text { which to leave }\end{array}$ & $\begin{array}{l}\text { Data from patients } \\
\text { can help to identify } \\
\text { possible } \\
\text { partnerships with } \\
\text { pharmaceutical } \\
\text { industry in the } \\
\text { development of } \\
\text { innovative } \\
\text { solutions }\end{array}$ \\
\hline $\begin{array}{l}\text { S03. Large amount } \\
\text { of organisation } \\
\text { information } \\
\text { available that } \\
\text { allows to compare } \\
\text { and assess } \\
\text { hospitals' } \\
\text { performance }\end{array}$ & $\begin{array}{l}\text { Identify hospitals } \\
\text { that are more } \\
\text { suitable for the } \\
\text { treatment of a } \\
\text { patient and share } \\
\text { information } \\
\text { between } \\
\text { hospitals to } \\
\text { achieve best } \\
\text { practices }\end{array}$ & $\begin{array}{l}\text { The comparison of } \\
\text { the information } \\
\text { from organisations } \\
\text { and the SPMS }\end{array}$ & $\begin{array}{l}\text { Promote the use } \\
\text { of data }\end{array}$ & $\begin{array}{l}\text { Portugal can } \\
\text { learn from other } \\
\text { countries how } \\
\text { they collect } \\
\text { information } \\
\text { from hospitals } \\
\text { and even enter } \\
\text { in contact with } \\
\text { those hospitals } \\
\text { to achieve best } \\
\text { practices } \\
\end{array}$ & $\begin{array}{l}\text { Promote } \\
\text { partnerships in the } \\
\text { development of } \\
\text { innovative } \\
\text { solutions. }\end{array}$ \\
\hline $\begin{array}{l}\text { S04. Healthcare } \\
\text { universities } \\
\text { courses that } \\
\text { implemented } \\
\text { entrepreneurship } \\
\text { disciplines in their } \\
\text { curricular plan }\end{array}$ & $\begin{array}{l}\text { The use of the } \\
\text { data can help to } \\
\text { test pilots. }\end{array}$ & $\begin{array}{l}\text { In assessing } \\
\text { institutions there } \\
\text { is the opportunity } \\
\text { to identify places } \\
\text { where to } \\
\text { implement, test } \\
\text { and validate } \\
\text { telemedicine } \\
\text { projects }\end{array}$ & $\begin{array}{l}\text { As telemedicine } \\
\text { will change the } \\
\text { business model, } \\
\text { managers need } \\
\text { to be aware of } \\
\text { how it can } \\
\text { impact the } \\
\text { performance of } \\
\text { the institution }\end{array}$ & \begin{tabular}{|l} 
Portugal can \\
learn from other \\
countries that \\
are more \\
advanced in the \\
practice of \\
telemedicine \\
and achieve \\
best practices at \\
a European level
\end{tabular} & $\begin{array}{l}\text { The availability of } \\
\text { data from patients, } \\
\text { even anonymous, } \\
\text { can help to identify } \\
\text { opportunities for } \\
\text { the development } \\
\text { of telemedicine }\end{array}$ \\
\hline
\end{tabular}




\begin{tabular}{|c|c|c|c|c|c|}
\hline & $\begin{array}{l}\text { Introduction of } \\
\text { informatic } \\
\text { software in the } \\
\text { healthcare } \\
\text { services }\end{array}$ & $\begin{array}{c}002 . \\
\text { Management of } \\
\text { clinical data } \\
\text { among } \\
\text { stakeholders }\end{array}$ & $\begin{array}{c}\text { O03. New } \\
\text { business models }\end{array}$ & $\begin{array}{l}\text { 004. Learn from } \\
\text { other countries }\end{array}$ & $\begin{array}{l}\text { O05. Manage } \\
\text { clinical data to } \\
\text { negotiate with } \\
\text { pharmaceutics and } \\
\text { assess medical } \\
\text { equipment in a } \\
\text { large scale }\end{array}$ \\
\hline $\begin{array}{l}\text { W01. } \\
\text { Technological } \\
\text { innovation } \\
\text { adoption is } \\
\text { presented by } \\
\text { the lack of } \\
\text { partnerships in } \\
\text { the ecosystem }\end{array}$ & $\begin{array}{l}\text { The access to this } \\
\text { data can help to } \\
\text { discover } \\
\text { innovation } \\
\text { opportunities }\end{array}$ & $\begin{array}{l}\text { The identification } \\
\text { of how } \\
\text { institutions are } \\
\text { performing can } \\
\text { help attract } \\
\text { companies to } \\
\text { collaborate with. }\end{array}$ & $\begin{array}{l}\text { A business model } \\
\text { composed by all } \\
\text { the parties and } \\
\text { their role must be } \\
\text { defined }\end{array}$ & $\begin{array}{l}\text { Other countries } \\
\text { are fostering the } \\
\text { connection } \\
\text { between } \\
\text { different parties } \\
\text { surrounding the } \\
\text { health } \\
\text { ecosystem (for } \\
\text { example, in } \\
\text { November 2019, } \\
\text { EHMA hosted a } \\
\text { conference with } \\
\text { this purpose) }\end{array}$ & $\begin{array}{l}\text { Achievement of } \\
\text { innovative solutions } \\
\text { that are really in } \\
\text { need in the market. } \\
\text { Moreover, the } \\
\text { involvement of } \\
\text { patients as an active } \\
\text { party can help to } \\
\text { better assess } \\
\text { innovations }\end{array}$ \\
\hline $\begin{array}{l}\text { W02. Lack of } \\
\text { funding to hire } \\
\text { hospital } \\
\text { innovation } \\
\text { managers }\end{array}$ & N/A & \begin{tabular}{|l|} 
The identification \\
of how \\
institutions are \\
performing can \\
help to \\
understand why \\
they do not hire \\
innovation \\
managers
\end{tabular} & $\begin{array}{l}\text { When developing } \\
\text { new business } \\
\text { models always } \\
\text { considering the } \\
\text { necessity of } \\
\text { hiring an } \\
\text { innovation } \\
\text { manager }\end{array}$ & $\begin{array}{l}\text { Innovation } \\
\text { managers are } \\
\text { frequently used } \\
\text { in other } \\
\text { countries, such } \\
\text { as Sweden. } \\
\text { Portugal needs } \\
\text { to understand } \\
\text { and learn how } \\
\text { others are doing } \\
\text { it }\end{array}$ & N/A \\
\hline $\begin{array}{l}\text { W03. Lack of a } \\
\text { national } \\
\text { healthcare } \\
\text { innovation } \\
\text { strategy }\end{array}$ & $\begin{array}{l}\text { The data can help } \\
\text { to identify if there } \\
\text { is or there is not } \\
\text { the need for this } \\
\text { strategy }\end{array}$ & $\begin{array}{l}\text { The data can help } \\
\text { to identify if } \\
\text { there is or there } \\
\text { is not the need } \\
\text { for this strategy }\end{array}$ & $\begin{array}{l}\text { Promote a value } \\
\text { chain composed } \\
\text { by different } \\
\text { stakeholders to } \\
\text { transfer } \\
\text { knowledge and } \\
\text { technology to } \\
\text { achieve } \\
\text { innovative } \\
\text { solutions }\end{array}$ & $\begin{array}{l}\text { Portugal needs } \\
\text { to analyse other } \\
\text { countries' } \\
\text { innovation } \\
\text { strategy and } \\
\text { learn how to } \\
\text { develop and } \\
\text { implement one }\end{array}$ & $\begin{array}{l}\text { The involvement of } \\
\text { the patients, that } \\
\text { are part of the } \\
\text { ecosystem and the } \\
\text { principal "customer" } \\
\text { can help to identify } \\
\text { opportunities for } \\
\text { the development of } \\
\text { the strategy }\end{array}$ \\
\hline $\begin{array}{l}\text { W04. The SMEs } \\
\text { and start-ups } \\
\text { not focused on } \\
\text { the } \\
\text { development of } \\
\text { products that } \\
\text { can be scaled up }\end{array}$ & $\begin{array}{l}\text { Data can help firm } \\
\text { achieve other } \\
\text { innovation } \\
\text { opportunities } \\
\text { beside service }\end{array}$ & $\begin{array}{l}\text { Data can help } \\
\text { companies } \\
\text { identify hospitals } \\
\text { to collaborate } \\
\text { with in the } \\
\text { development of } \\
\text { innovative } \\
\text { solutions. }\end{array}$ & $\begin{array}{l}\text { Englobe } \\
\text { companies in } \\
\text { R\&D phases } \\
\text { throughout the } \\
\text { entire business } \\
\text { model }\end{array}$ & $\begin{array}{l}\text { Portugal needs } \\
\text { to learn from } \\
\text { other countries } \\
\text { how they are } \\
\text { managing the } \\
\text { introduction of } \\
\text { home- } \\
\text { companies in } \\
\text { other phases } \\
\text { besides service } \\
\text { delivering }\end{array}$ & $\begin{array}{l}\text { The data from } \\
\text { patients can help } \\
\text { companies to } \\
\text { identify market } \\
\text { opportunities }\end{array}$ \\
\hline $\begin{array}{l}\text { W05. Significant } \\
\text { gap between } \\
\text { R\&D and market }\end{array}$ & $\begin{array}{l}\text { Data can help to } \\
\text { achieve innovative } \\
\text { solutions that are } \\
\text { in need in the } \\
\text { market }\end{array}$ & \begin{tabular}{|l|} 
Hospitals that are \\
more suitable for \\
a certain \\
innovation can be \\
identified as \\
academic \\
hospitals in which \\
tests and pilots \\
can be carried out \\
and act as \\
example for
\end{tabular} & $\begin{array}{l}\text { Need to adapt } \\
\text { the business } \\
\text { model from } \\
\text { hospitals as } \\
\text { centres of testing }\end{array}$ & $\begin{array}{l}\text { Portugal can } \\
\text { learn from other } \\
\text { countries in the } \\
\text { assessment and } \\
\text { selection of } \\
\text { which } \\
\text { innovations are } \\
\text { in need and how } \\
\text { to implement it }\end{array}$ & $\begin{array}{l}\text { With the data from } \\
\text { patients, } \\
\text { innovations that are } \\
\text { really in need can be } \\
\text { identified. A more } \\
\text { effective } \\
\text { implementation can } \\
\text { be achieved because } \\
\text { it considers the } \\
\text { human factor. }\end{array}$ \\
\hline
\end{tabular}




\begin{tabular}{|c|c|c|c|c|c|}
\hline & $\begin{array}{l}\text { Introduction of } \\
\text { informatic } \\
\text { software in the } \\
\text { healthcare } \\
\text { services }\end{array}$ & $\begin{array}{c}002 . \\
\text { Management of } \\
\text { clinical data } \\
\text { among } \\
\text { stakeholders }\end{array}$ & $\begin{array}{c}\text { O03. New } \\
\text { business models }\end{array}$ & $\begin{array}{l}\text { 004. Learn from } \\
\text { other countries }\end{array}$ & $\begin{array}{l}\text { O05. Manage } \\
\text { clinical data to } \\
\text { negotiate with } \\
\text { pharmaceutics and } \\
\text { assess medical } \\
\text { equipment in a } \\
\text { large scale }\end{array}$ \\
\hline & & $\begin{array}{l}\text { others to do the } \\
\text { same }\end{array}$ & & & \\
\hline $\begin{array}{l}\text { W06. } \\
\text { Knowledge } \\
\text { creation process } \\
\text { is focused on } \\
\text { the academia } \\
\text { with few } \\
\text { contacts with } \\
\text { the healthcare } \\
\text { institutions }\end{array}$ & $\begin{array}{l}\text { Data can help to } \\
\text { achieve innovative } \\
\text { solutions that are } \\
\text { in need in the } \\
\text { market }\end{array}$ & $\begin{array}{l}\text { Hospitals can } \\
\text { help researchers } \\
\text { to connect more } \\
\text { with companies } \\
\text { establishing } \\
\text { meetings } \\
\text { between the } \\
\text { parties to develop } \\
\text { solutions in need } \\
\text { to improve the } \\
\text { hospital } \\
\text { performance }\end{array}$ & $\begin{array}{l}\text { Consider the role } \\
\text { of the parties in } \\
\text { the business } \\
\text { model and the } \\
\text { approach that } \\
\text { can guide the } \\
\text { process }\end{array}$ & $\begin{array}{l}\text { Need for } \\
\text { researchers to } \\
\text { analyse case } \\
\text { studies from } \\
\text { other countries } \\
\text { and even } \\
\text { contact those } \\
\text { researchers to } \\
\text { see how the } \\
\text { contact is } \\
\text { established and } \\
\text { what are the } \\
\text { benefits }\end{array}$ & $\begin{array}{l}\text { In developing case } \\
\text { studies with patients } \\
\text { and accessing data } \\
\text { from them, } \\
\text { researchers can } \\
\text { understand how } \\
\text { they can impact the } \\
\text { real world with the } \\
\text { contact established } \\
\text { with companies in } \\
\text { the development of } \\
\text { innovative solutions }\end{array}$ \\
\hline $\begin{array}{l}\text { W07. Patients } \\
\text { are not involved } \\
\text { in the } \\
\text { assessment of } \\
\text { innovative } \\
\text { solutions }\end{array}$ & $\begin{array}{l}\text { The correct } \\
\text { management of } \\
\text { data can allow to } \\
\text { select groups of } \\
\text { patients to assess } \\
\text { certain } \\
\text { technologies } \\
\text { depending on the } \\
\text { health problem }\end{array}$ & $\begin{array}{l}\text { Groups of } \\
\text { patients in the } \\
\text { hospitals can be } \\
\text { identified as } \\
\text { possible sources } \\
\text { to be involved in } \\
\text { the innovation } \\
\text { process. } \\
\text { Managers and } \\
\text { those responsible } \\
\text { for the innovation } \\
\text { process need to } \\
\text { be open for the } \\
\text { patients' opinions }\end{array}$ & $\begin{array}{l}\text { Involve the } \\
\text { patients as a new } \\
\text { approach for } \\
\text { innovation as a } \\
\text { value-based } \\
\text { healthcare } \\
\text { approach }\end{array}$ & $\begin{array}{l}\text { Patients should } \\
\text { be aware of } \\
\text { international } \\
\text { case studies and } \\
\text { how the patients } \\
\text { can act along the } \\
\text { innovation } \\
\text { process to } \\
\text { understand the } \\
\text { importance of } \\
\text { their role. }\end{array}$ & $\begin{array}{l}\text { Data from patients } \\
\text { can help identify } \\
\text { groups of people } \\
\text { that are available to } \\
\text { participate in the } \\
\text { innovation process } \\
\text { according to the } \\
\text { necessities of the } \\
\text { innovative solution } \\
\text { and the patient }\end{array}$ \\
\hline
\end{tabular}




\begin{tabular}{|c|c|c|c|c|c|}
\hline & $\begin{array}{l}\text { T02. Lack of } \\
\text { capacity for start- } \\
\text { ups to access } \\
\text { funding } \\
\text { opportunities to } \\
\text { scale up }\end{array}$ & $\begin{array}{l}\text { T03. The new } \\
\text { EU data policy } \\
\text { obligates to a } \\
\text { restrictive use } \\
\text { of data }\end{array}$ & $\begin{array}{l}\text { T04. Lack of } \\
\text { time to market } \\
\text { due to reduced } \\
\text { funding for } \\
\text { SMEs and start- } \\
\text { ups }\end{array}$ & $\begin{array}{l}\text { T05. The human } \\
\text { is frequently } \\
\text { ignored when } \\
\text { considering the } \\
\text { adoption of new } \\
\text { technologies }\end{array}$ & $\begin{array}{l}\text { T07. The } \\
\text { healthcare sector } \\
\text { in Portugal is } \\
\text { mainly } \\
\text { composed by } \\
\text { public hospitals } \\
\text { and the Ministry } \\
\text { of Health is a } \\
\text { direct competitor } \\
\text { with the private } \\
\text { healthcare } \\
\text { technological } \\
\text { organisations } \\
\end{array}$ \\
\hline $\begin{array}{l}\text { S01. Public platform } \\
\text { that gives importance } \\
\text { to innovation in the } \\
\text { healthcare sector }\end{array}$ & $\begin{array}{l}\text { Considering the } \\
\text { data from the } \\
\text { platform there is } \\
\text { the opportunity } \\
\text { to identify where } \\
\text { funding can be } \\
\text { provided }\end{array}$ & $\begin{array}{l}\text { The availability } \\
\text { of the } \\
\text { information can } \\
\text { be used by } \\
\text { organisations to } \\
\text { identify health } \\
\text { institutions to } \\
\text { collaborate with }\end{array}$ & $\begin{array}{l}\text { Considering the } \\
\text { data from the } \\
\text { platform there } \\
\text { is the } \\
\text { opportunity to } \\
\text { identify where } \\
\text { funding can be } \\
\text { provided }\end{array}$ & N/A & $\begin{array}{l}\text { This may lead the } \\
\text { institution to not } \\
\text { have the } \\
\text { autonomy to } \\
\text { choose who to } \\
\text { collaborate with }\end{array}$ \\
\hline $\begin{array}{l}\text { S02. Structured and } \\
\text { integrated information } \\
\text { about what is being } \\
\text { done in the healthcare } \\
\text { sector, available for all } \\
\text { users }\end{array}$ & $\begin{array}{l}\text { Considering the } \\
\text { data from the } \\
\text { platform there is } \\
\text { the opportunity } \\
\text { to identify where } \\
\text { funding can be } \\
\text { provided }\end{array}$ & $\begin{array}{l}\text { The availability } \\
\text { of the } \\
\text { information } \\
\text { must be } \\
\text { analysed } \\
\text { according to the } \\
\text { new norms }\end{array}$ & $\begin{array}{l}\text { Considering the } \\
\text { data from the } \\
\text { platform there } \\
\text { is the } \\
\text { opportunity to } \\
\text { identify where } \\
\text { funding can be } \\
\text { provided }\end{array}$ & $\begin{array}{l}\text { The users should } \\
\text { be involved and } \\
\text { be able to give } \\
\text { their opinion } \\
\text { since they are } \\
\text { the human } \\
\text { factor that } \\
\text { needs to be } \\
\text { considered }\end{array}$ & $\begin{array}{l}\text { This may lead the } \\
\text { institution to not } \\
\text { have the } \\
\text { autonomy to } \\
\text { choose who to } \\
\text { collaborate with }\end{array}$ \\
\hline $\begin{array}{l}\text { S03. Large amount of } \\
\text { organisation } \\
\text { information available } \\
\text { that allows to compare } \\
\text { and assess } \\
\text { hospitals' performance }\end{array}$ & $\begin{array}{l}\text { Considering the } \\
\text { data from the } \\
\text { platform there is } \\
\text { the opportunity } \\
\text { to identify where } \\
\text { funding can be } \\
\text { provided }\end{array}$ & $\begin{array}{l}\text { The availability } \\
\text { of the } \\
\text { information } \\
\text { must be } \\
\text { analysed } \\
\text { according to the } \\
\text { new norms }\end{array}$ & $\begin{array}{l}\text { Considering the } \\
\text { data from the } \\
\text { platform there } \\
\text { is the } \\
\text { opportunity to } \\
\text { identify where } \\
\text { funding can be } \\
\text { provided }\end{array}$ & $\begin{array}{l}\text { Consider not } \\
\text { only the } \\
\text { organisations' } \\
\text { information but } \\
\text { also the } \\
\text { involvement of } \\
\text { patients in the } \\
\text { process to } \\
\text { consider a value- } \\
\text { based } \\
\text { healthcare } \\
\text { approach } \\
\end{array}$ & $\begin{array}{l}\text { This may lead the } \\
\text { institution to not } \\
\text { have the } \\
\text { autonomy to } \\
\text { choose who to } \\
\text { collaborate with }\end{array}$ \\
\hline $\begin{array}{l}\text { S04. Healthcare } \\
\text { universities courses } \\
\text { that implemented } \\
\text { entrepreneurship } \\
\text { disciplines in their } \\
\text { curricular plan }\end{array}$ & $\begin{array}{l}\text { Opportunity to } \\
\text { develop } \\
\text { programmes were } \\
\text { students analyse } \\
\text { those start-ups } \\
\text { and develop } \\
\text { projects of what } \\
\text { can be done to } \\
\text { improve their } \\
\text { performance }\end{array}$ & N/A & N/A & $\begin{array}{l}\text { Foster the } \\
\text { development of } \\
\text { case studies of } \\
\text { how innovation } \\
\text { processes occur } \\
\text { in healthcare } \\
\text { institutions }\end{array}$ & $\begin{array}{l}\text { This may lead the } \\
\text { institution to not } \\
\text { have the } \\
\text { autonomy to } \\
\text { choose who to } \\
\text { collaborate with }\end{array}$ \\
\hline
\end{tabular}




\begin{tabular}{|c|c|c|c|c|c|}
\hline & $\begin{array}{l}\text { T02. Lack of } \\
\text { capacity for start- } \\
\text { ups to access } \\
\text { funding } \\
\text { opportunities to } \\
\text { scale up }\end{array}$ & $\begin{array}{l}\text { T03. The new EU } \\
\text { data policy } \\
\text { obligates to a } \\
\text { restrictive use of } \\
\text { data }\end{array}$ & $\begin{array}{l}\text { T04. Lack of time } \\
\text { to market due to } \\
\text { reduced funding } \\
\text { for SMEs and } \\
\text { start-ups }\end{array}$ & $\begin{array}{l}\text { T05. The human is } \\
\text { frequently } \\
\text { ignored when } \\
\text { considering the } \\
\text { adoption of new } \\
\text { technologies }\end{array}$ & $\begin{array}{l}\text { T07. The } \\
\text { healthcare sector } \\
\text { in Portugal is } \\
\text { mainly composed } \\
\text { by public } \\
\text { hospitals and the } \\
\text { Ministry of Health } \\
\text { is a direct } \\
\text { competitor with } \\
\text { the private } \\
\text { healthcare } \\
\text { technological } \\
\text { organisations }\end{array}$ \\
\hline $\begin{array}{l}\text { W01. } \\
\text { Technological } \\
\text { innovation } \\
\text { adoption is } \\
\text { presented by } \\
\text { the lack of } \\
\text { partnerships in } \\
\text { the ecosystem }\end{array}$ & $\begin{array}{l}\text { It is necessary to } \\
\text { involve all } \\
\text { stakeholders }\end{array}$ & $\begin{array}{l}\text { Considering the } \\
\text { knowledge transfer } \\
\text { involved in } \\
\text { collaborations, the } \\
\text { correct use of data } \\
\text { must be assured }\end{array}$ & $\begin{array}{l}\text { If companies } \\
\text { want to } \\
\text { incorporate high } \\
\text { levels of } \\
\text { knowledge in } \\
\text { their exportable } \\
\text { products, } \\
\text { networks can } \\
\text { provide the } \\
\text { easier access to } \\
\text { know-how, } \\
\text { methods and } \\
\text { techniques. }\end{array}$ & $\begin{array}{l}\text { Due to the } \\
\text { reduced } \\
\text { importance given } \\
\text { to the human } \\
\text { factor also the } \\
\text { role of patients in } \\
\text { the ecosystem is } \\
\text { not clearly defined }\end{array}$ & $\begin{array}{l}\text { Due to the power } \\
\text { of the Minister, } \\
\text { this only will } \\
\text { reduce when } \\
\text { hospitals start to } \\
\text { gain more } \\
\text { autonomy in } \\
\text { choosing who to } \\
\text { collaborate with }\end{array}$ \\
\hline $\begin{array}{l}\text { W02. Lack of } \\
\text { funding to hire } \\
\text { hospital } \\
\text { innovation } \\
\text { managers }\end{array}$ & N/A & N/A & $\begin{array}{l}\text { The reduction of } \\
\text { funding made it } \\
\text { difficult to hire } \\
\text { such expertise } \\
\text { which affects the } \\
\text { performance of } \\
\text { the innovation in } \\
\text { the hospital, } \\
\text { because } \\
\text { managers are } \\
\text { worried with } \\
\text { aspects "more } \\
\text { important" than } \\
\text { innovation }\end{array}$ & N/A & $\begin{array}{l}\text { Due to the power } \\
\text { of the Minister, } \\
\text { this only will } \\
\text { reduce when } \\
\text { hospitals start to } \\
\text { gain more } \\
\text { autonomy in } \\
\text { choosing who to } \\
\text { collaborate with }\end{array}$ \\
\hline $\begin{array}{l}\text { W03. Lack of a } \\
\text { national } \\
\text { healthcare } \\
\text { innovation } \\
\text { strategy }\end{array}$ & $\begin{array}{l}\text { Define an } \\
\text { healthcare } \\
\text { innovation } \\
\text { strategy involving } \\
\text { start-ups }\end{array}$ & $\begin{array}{l}\text { This strategy, must } \\
\text { consider how to } \\
\text { collect and manage } \\
\text { data from } \\
\text { hospitals, } \\
\text { companies, } \\
\text { patients, etc }\end{array}$ & N/A & $\begin{array}{l}\text { Patients and } \\
\text { group of } \\
\text { representatives of } \\
\text { patients need to } \\
\text { be heard }\end{array}$ & $\begin{array}{l}\text { The strategy must } \\
\text { be developed and } \\
\text { hospitals } \\
\text { managers need to } \\
\text { enhance the fact } \\
\text { that hospitals } \\
\text { need more } \\
\text { autonomy }\end{array}$ \\
\hline $\begin{array}{l}\text { W04. The SMEs } \\
\text { and start-ups } \\
\text { not focused on } \\
\text { the } \\
\text { development of } \\
\text { products that } \\
\text { can be scaled } \\
\text { up }\end{array}$ & $\begin{array}{l}\text { Interconnect } \\
\text { companies within } \\
\text { networks, in order } \\
\text { to scale up } \\
\text { businesses }\end{array}$ & $\begin{array}{l}\text { The new EU norms } \\
\text { make it clear that } \\
\text { companies must } \\
\text { provide public } \\
\text { reports of their } \\
\text { activities. }\end{array}$ & $\begin{array}{l}\text { Reducing } \\
\text { budgets of } \\
\text { providers of } \\
\text { health and } \\
\text { research may } \\
\text { reduce } \\
\text { companies' } \\
\text { incentives to } \\
\text { maintain (or } \\
\text { create new) } \\
\text { connections with } \\
\text { enterprises } \\
\text { dedicated to the } \\
\text { same area of } \\
\text { activities }\end{array}$ & $\begin{array}{l}\text { This proves that } \\
\text { the human factor } \\
\text { is neglected most } \\
\text { of the time }\end{array}$ & $\begin{array}{l}\text { Due to the power } \\
\text { of the Minister, } \\
\text { this only will } \\
\text { reduce when } \\
\text { hospitals start to } \\
\text { gain more } \\
\text { autonomy in } \\
\text { choosing who to } \\
\text { collaborate with }\end{array}$ \\
\hline
\end{tabular}




\begin{tabular}{|c|c|c|c|c|c|}
\hline & $\begin{array}{l}\text { T02. Lack of } \\
\text { capacity for start- } \\
\text { ups to access } \\
\text { funding } \\
\text { opportunities to } \\
\text { scale up }\end{array}$ & $\begin{array}{l}\text { T03. The new EU } \\
\text { data policy } \\
\text { obligates to a } \\
\text { restrictive use of } \\
\text { data }\end{array}$ & $\begin{array}{l}\text { T04. Lack of time } \\
\text { to market due to } \\
\text { reduced funding } \\
\text { for SMEs and } \\
\text { start-ups }\end{array}$ & $\begin{array}{l}\text { T05. The human is } \\
\text { frequently } \\
\text { ignored when } \\
\text { considering the } \\
\text { adoption of new } \\
\text { technologies }\end{array}$ & $\begin{array}{l}\text { T07. The } \\
\text { healthcare sector } \\
\text { in Portugal is } \\
\text { mainly composed } \\
\text { by public } \\
\text { hospitals and the } \\
\text { Ministry of Health } \\
\text { is a direct } \\
\text { competitor with } \\
\text { the private } \\
\text { healthcare } \\
\text { technological } \\
\text { organisations }\end{array}$ \\
\hline $\begin{array}{l}\text { W05. Significant } \\
\text { gap between } \\
\text { R\&D and } \\
\text { market }\end{array}$ & $\begin{array}{l}\text { Start-ups should } \\
\text { search for new } \\
\text { funding } \\
\text { opportunities }\end{array}$ & $\begin{array}{l}\text { The measures } \\
\text { introduced by the } \\
\text { EU can affect the } \\
\text { implementation of } \\
\text { innovative } \\
\text { solutions due more } \\
\text { bureaucratic } \\
\text { processes to assure } \\
\text { that the } \\
\text { information is } \\
\text { correctly used }\end{array}$ & $\begin{array}{l}\text { Reducing } \\
\text { budgets of } \\
\text { providers of } \\
\text { health and } \\
\text { research may } \\
\text { reduce } \\
\text { companies' } \\
\text { incentives to } \\
\text { maintain (or } \\
\text { create new) } \\
\text { connections with } \\
\text { enterprises } \\
\text { dedicated to the } \\
\text { same area of } \\
\text { activities }\end{array}$ & $\begin{array}{l}\text { Understand more } \\
\text { deeply the } \\
\text { population to } \\
\text { facilitate the } \\
\text { development and } \\
\text { introduction of } \\
\text { new technologies }\end{array}$ & $\begin{array}{l}\text { Due to the power } \\
\text { of the Minister, } \\
\text { this only will } \\
\text { reduce when } \\
\text { hospitals start to } \\
\text { gain more } \\
\text { autonomy in } \\
\text { choosing who to } \\
\text { collaborate with }\end{array}$ \\
\hline $\begin{array}{l}\text { W06. } \\
\text { Knowledge } \\
\text { creation process } \\
\text { is focused on } \\
\text { the academia } \\
\text { with few } \\
\text { contacts with } \\
\text { the healthcare } \\
\text { institutions }\end{array}$ & $\begin{array}{l}\text { Start-ups can be } \\
\text { used as places } \\
\text { where to test } \\
\text { researchers' ideas } \\
\text { and considering } \\
\text { the dimension of } \\
\text { the university, the } \\
\text { start-up can make } \\
\text { a deal to use it in } \\
\text { their favour } \\
\text { through for } \\
\text { example } \\
\text { promotion of } \\
\text { collaboration } \\
\text { between the } \\
\text { parties }\end{array}$ & $\begin{array}{l}\text { The knowledge } \\
\text { transferred } \\
\text { between the } \\
\text { parties must be } \\
\text { managed according } \\
\text { to the EU norms } \\
\text { which can act as a } \\
\text { disadvantage due } \\
\text { to the bureaucratic } \\
\text { processes }\end{array}$ & $\begin{array}{l}\text { The reduction of } \\
\text { funding made it } \\
\text { difficult to } \\
\text { develop } \\
\text { incentive } \\
\text { programmes }\end{array}$ & $\begin{array}{l}\text { Development of } \\
\text { case studies. }\end{array}$ & $\begin{array}{l}\text { Case studies can } \\
\text { help to proof this } \\
\text { as well as } \\
\text { identifying } \\
\text { solutions for this } \\
\text { problem (e.g. a } \\
\text { reformulation of } \\
\text { the system) }\end{array}$ \\
\hline $\begin{array}{l}\text { W07. Patients } \\
\text { are not involved } \\
\text { in the } \\
\text { assessment of } \\
\text { innovative } \\
\text { solutions }\end{array}$ & $\begin{array}{l}\text { Need for more } \\
\text { funding and } \\
\text { recognition of } \\
\text { start-ups as safe } \\
\text { places }\end{array}$ & $\begin{array}{l}\text { The involvement of } \\
\text { the patients must } \\
\text { assure that the } \\
\text { patient authorises } \\
\text { the use of the } \\
\text { information }\end{array}$ & $\begin{array}{l}\text { The reduction of } \\
\text { funding made it } \\
\text { difficult to } \\
\text { develop } \\
\text { incentive } \\
\text { programmes }\end{array}$ & $\begin{array}{l}\text { Understand more } \\
\text { deeply the } \\
\text { population to } \\
\text { facilitate the } \\
\text { development and } \\
\text { introduction of } \\
\text { new technologies }\end{array}$ & $\begin{array}{l}\text { Patients are not } \\
\text { seen as part of the } \\
\text { ecosystem by the } \\
\text { government. } \\
\text { There is the need } \\
\text { to include the } \\
\text { people }\end{array}$ \\
\hline
\end{tabular}

